Nina Kisin ${ }^{10}$

Visoka poslovna škola strukovnih studija

Novi Sad
UDC: $371.3:: 811.111$

DOI: $10.19090 /$ ps.2018.2.170-178

Primljen: 10.12.2018.

Prihvaćen: 7.3.2019.

ORIGINALNI NAUČNI RAD

\title{
UPOTREBA AFEKTIVNIH STRATEGIJA ZA UČENJE U NASTAVI POSLOVNOG ENGLESKOG JEZIKA ${ }^{11}$
}

\begin{abstract}
Rezime
Ovaj rad odnosi se na učestalost upotrebe afektivnih strategija u nastavi engleskog jezika. Afektivne strategije se koriste u manjoj meri, jer se učenici na početku učenja osećaju inhibirano da bi govorili o svojim strahovima $i$ anksioznosti. Istraživanje je sprovedeno početkom letnjeg semestra školske 2014/2015. godine sa studentima Visoke poslovne škole iz Novog Sada. Istraživanje ima za cilj da dokaže da li i u kojoj meri studenti koriste afektivne strategije za učenje poslovnog engleskog jezika. Koristiće se kvantitativni metod obrade podataka dobijenih iz rezultata standardizovanog upitnika za strategije (ISUJ, eng. Strategy Inventory for Language Learning, SILL) autorke Rebeke Oksford (Oxford, 1990). Rezultati istraživanja pokazuju da se afektivne strategije koriste u najmanjoj meri. Ovaj rad ima za cilj propagiranje upotrebe afektivnih strategija u nastavi engleskog jezika od strane učenika, budući da se afektivne strategije koriste u manjoj meri.
\end{abstract}

Ključne reči: afektivne strategije, poslovni engleski jezik.

\section{Uvod}

Rebeka Oksford, autorka koja je vršila opsežna istraživanja u oblasti strategija za učenje, definiše strategije kao: ,specifične radnje, ponašanja, koraci ili tehnike - kao što je traženje partnera za konverzaciju ili ohrabrivanje kako bi se suočilo sa teškim jezičkim

\footnotetext{
${ }^{10}$ ninakisin.vps@gmail.com

${ }^{11}$ Isti uzorak korišćen je za potrebe rada Kisin, N. (2015) The Relationship between Metacognition and Business English Learning, ELTA Journal An International and Interdisciplinary Journal of the ELT Practice and Research 3 (3), English Language Teachers' Association, Belgrade, Serbia, i Kisin, N. (2017) Business English Learners' Motivation, Philologica Jassyensia 13, 1 (25).
} 
zadatkom - a koje se koriste od strane učenika kako bi poboljšali svoje učenje“ (Scarcella \& Oxford, 1992: 63 kako se navodi u Oxford, 2003: 2). Oksford, definišući strategije, pominje i koren reči strategija (potiče od gr. strategia), a reč je podrazumevala veštinu ratovanja preduzete korake ili radnje kako bi se dobio rat (Oxford, 1990 kako se navodi u Oxford, 2003: 8).

Afektivne strategije uključuju identifikovanje nivoa anksioznosti, pričanje o osećanjima u toku učenja stranog jezika itd. Kod afektivnih strategija naglasak je na kontrolisanju sopstvenog ponašanja tokom učenja (Chamot i Kupper, 1989: 247). Ove strategije se koriste sa malom učestalošću, jer se učenici na početku učenja osećaju inhibirano da bi govorili o svojim strahovima i anksioznosti. Prethodna istraživanja pokazala su da studenti sa znanjem drugog stranog jezika znatno ređe upotrebljavaju kognitivne, društvene i afektivne strategije (Karlak, 2014:184).

U našoj zemlji, Ivana Ćirković-Miladinović istraživala je zastupljenost afektivnih strategija učenja engleskog jezika kod studenata na nematičnim fakultetima. Afektivne strategije pomažu u razvijanju samopouzdanja koje je potrebno studentima kako bi se aktivno uključili u proces učenja engleskog jezika ali i da bi razvili komunikativne sposobnosti potrebne za kvalitetno usmeno izlaganje (Oxford, 1990: 8 kako se navodi u ĆirkovićMiladinović, 2014: 175). Afektivne strategije učenja engleskog jezika su slabo zastupljene, studentima je stalo do mišljenja kolega o njihovom znanju, ali i stav nastavnika utiče na motivaciju, stavove i ishode učenja engleskog jezika (Ćirković-Miladinović, 2014: 5).

U istraživanju Rebeke Oksford (Oxford) afektivne strategije su u manjoj upotrebi od strane učenika stranog jezika. Učenicima na naprednijem nivou znanja ove strategije nisu više potrebne u tolikoj meri, jer se smanjuje strah od pravljenja grešaka kako učenici napreduju u znanju (Oxford, 2003: 14).

Sintija J. Vajt (White 1993) je u svom istraživanju strategija za učenje stranih jezika koristila upitnik $(\mathrm{N}=417)$ i tvz. „proceduru verbalnog izveštaja“ (eng. verbal report procedure) sa poduzorkom grupe ispitanika $(\mathrm{N}=37)$. Vajt (White 1993) ističe da su stilovi učenja i godine učenika značajni faktori za izbor strategija za učenje jezika. Interesantan rezultat istraživanja je da učenici koji uče na daljinu (eng. distance learners) koriste afektivne strategije u većoj meri. Očekivano je, međutim, da kod ovakve vrste učenja izostaje kontakt na relaciji nastavnik-student, a koji se dešava u fizičkom okruženju, među vršnjacima ili ostalim studentima (u učionici), pa je moguće da je usled toga afektivni filter niži, kao i inhibiranost studenata i strah od pravljenja grešaka (White 1993). 
Prema nekim istraživanjima, karakter studenata takođe je uticao na zastupljenost afektivnih strategija učenja engleskog jezika, jer je njihova upotreba uslovljena regulacijom osećanja, stavova i percepcijom samog procesa učenja (Oxford, 1990: 167-168 kako se navodi u Ćirković-Miladinović, 2014: 175). Studenti koji osećaju strah ili tremu (tvz. jezička anksioznost u učenju jezika) imaju lošija postignuća u oblasti usmenog izlaganja (ĆirkovićMiladinović, 2014:171).

Razumevanje poruke ili učenje novih leksičkih jedinica na ciljnom jeziku može biti smanjeno visokim nivoom procesne (biološki, psihološki ili socijalni pocesi) jezičke anksioznosti (MacIntyre i Gardner, 1994 kako se navodi u Kostić-Bobanović i AmbrosiRandić, 2006: 285). Mnoga istraživanja izvestila su o uticaju anksioznosti na izbor strategija za učenje jezika (Oxford i Ehrman, 1995; Mihaljević Djigunović, 2001 kako se navodi u Kostić-Bobanović i Ambrosi-Randić, 2006: 286).

Upotreba strategija učenja za usmeno izlaganje bila je ispitana koristeći upitnik Moire Kostić-Bobanović (2004). Upitnik je imao za cilj da ispitanici izveste o učestalosti sa kojom su upotrebljavali određene strategije za usmeno izlaganje na engleskom jeziku. U drugom istraživanju jezičke anksoznosti (MacIntyre i Gardner 1989) upitnik je sadržao pitanja koja su se odnosila na stid učenika da dobrovoljno daju odgovore na času; nesigurnost pri govorenju engleskog jezika na času; mišljenje da drugi znaju engleski bolje od njih; nervoza usled govorenja na engleskom jeziku na času i strah od ismevanja od strane drugih (KostićBobanović i Ambrosi-Randić, 2006: 288).

Rezultati gore navedenog istraživanja dobijeni koristeći "Student-Newman-Keuls" post hoc test ukazuju na to da su učenici srednje škole pokazali niži nivo anksioznosti od učenika osnovne škole i studenata (Ibid: 289). Što se tiče prethodnog jezičkog iskustva kao faktora u učenju jezika, uzorak učenika osnovne škole predstavlja manje pozitivno iskustvo nego uzorak srednjoškolaca i studenata. Nema razlike između prethodnog jezičkog iskustva između uzoraka srednjoškolaca i studenata. Generalno, rezultati ovog istraživanja pokazuju da mlađi ispitanici koriste više strategija od starijih kolega koji su učili engleski jezik duži period. Univerzitetski studenti su više upotrebljavali strategije za učenje pri usmenom izlaganju nego srednjoškolci (osnovnoškolci su se na početku učenja engleskog kao stranog jezika više osnažili da razvijaju usmenu komunikaciju nego ostale veštine) (Ibid: 294-296).

Razumevanje poruke ili učenje novih leksičkih jedinica na ciljnom jeziku može biti smanjeno visokim nivoom procesne (biološki, psihološki ili socijalni pocesi) jezičke anksioznosti (MacIntyre i Gardner, 1994 kako se navodi u Kostić-Bobanović i AmbrosiRandić, 2006: 285). Mnoga istraživanja izvestila su o uticaju anksioznosti na izbor strategija 
za učenje jezika (Oxford i Ehrman, 1995; Mihaljević Djigunović, 2001 kako se navodi u Kostić-Bobanović i Ambrosi-Randić, 2006: 286).

\section{Inventar strategija za učenje jezika (ISUJ)}

Inventar strategija za učenje jezika (engl. Strategy Inventory for Language Learning, ISUJ) Rebeke Oksford (Rebecca Oxford) sadrži ukupno 50 iskaza u vezi sa strategijama za učenje stranog (engleskog) jezika, a koje su deo taksonomije strategija, tj. njihove podele u šest grupa. Naime, Rebeka Oksford (1990) klasifikovala je strategije učenja engleskog jezika u šest grupa odn. šest segmenata A-F, koji predstavljaju taksonomiju strategija za učenje jezika. To su:

1. Segment A: Strategije pamćenja

2. Segment B: Kognitivne strategije

3. Segment C: Kompenzatorne strategije

4. Segment D: Metakognitivne strategije

5. Segment E: Afektivne strategije

6. Segment F: Društvene strategije

Ovo je najpotpunija klasifikacija strategija, a kroz Inventar strategija za učenje jezika jasno se oslikava učestalost upotrebe neke od strategija. Nedostaci ovog upitnika su u tome što su „odgovori dosta ograničeni, ispitanik možda ne želi da bude potpuno iskren prilikom odgovaranja, ne postoji uvid u to da li je ispitanik razumeo pitanje na pravi način“" (Gao, 2004: 5 kako se navodi u Ćirković-Miladinović, 2014: 108).

\section{Metodi prikupljanja podataka}

U ovom istraživanju korišćeni su kvantitativni metodi prikupljanja podataka: upitnik za strategije autorke Rebeke Oksford (Oxford 1990). Početkom letnjeg semestra školske 2014/2015. godine, 50 studenata Visoke poslovne škole iz Novog Sada popunilo je anketni upitnik - Likertovu skalu procene dizajniranu od strane Rebeke Oksford, Inventar strategija za učenje jezika, ISUJ, engl. Strategy Inventory for Language Learning (SILL). Prevod pitanja iz upitnika sa engleskog na srpski jezik nalazi se u disertaciji Zastupljenost afektivnih strategija učenja engleskog jezika kod studenata na nematičnim fakultetima autorke Ivane Ćirković - Miladinović (Ćirković-Miladinović, I. 2014). 


\section{Opis uzorka}

Istraživanje je počelo tako što su studenti Visoke poslovne škole iz Novog Sada popunili inicijalni upitnik, čiji je cilj bio da prikupi demografske podatke od ispitanika. To uključuje opšte podatke o studentima (studijsku godinu, pol, studijski programi, broj godina učenja engleskog jezika, prosečnu ocenu u srednjoj školi i tokom studija; znanje drugog stranog jezika).

\begin{tabular}{|l|c|c|c|c|}
\hline & Minimum & Maximum & Aritmetička sredina & $\begin{array}{c}\text { Standardna } \\
\text { devijacija }\end{array}$ \\
\hline starost & 19.00 & 25.00 & 21.9348 & 1.74359 \\
\hline $\begin{array}{l}\text { godine učenja } \\
\text { engleskog jezika }\end{array}$ & 2.00 & 12.00 & 7.3125 & 3.45276 \\
\hline ocena iz engleskog u SŠ & 2.00 & 5.00 & 3.8200 & .96235 \\
\hline $\begin{array}{l}\text { ocena iz engleskog } \\
\text { tokom studija }\end{array}$ & 6.00 & 10.00 & 7.6200 & 1.19335 \\
\hline
\end{tabular}

Tabela 1. Minimalni i maksimalni rezultati, aritmetičke sredine i standardne devijacije za varijable: starost, godine učenja engleskog jezika, ocena iz engleskog u Š́, ocena iz engleskog tokom studija

Ispitanici muškog pola obuhvataju 44\% uzorka, dok je ispitanica 56\%. Svi ispitanici su sa druge godine osnovnih studija.

Najkraći period učenja engleskog jezika je 2 godine, najduži je 12 godina, dok u proseku ispitanici uče engleski jezik oko 7 godina. Najniža ocena iz engleskog jezika u srednjoj školi je dovoljan 2, dok je najveća odličan 5, a u proseku ispitanici su imali vrlo dobar uspeh iz engleskog jezika, odnosno ocenu 3,8. Tokom studija, najniža ocena im je 6, dok je najviša 10, a u proseku su imali ocenu 7,6.

Najveći procenat ispitanika je na studijskom programu Preduzetnički biznis, oni čine 48\% uzorka, potom sledi grupa ispitanika koja je na Finansijskom poslovanju, koja obuhvata $28 \%$ uzorka. Ispitanici na studijskom programu Trgovina i međunarodno poslovanje obuhvataju $24 \%$ uzorka.

Više od polovine uzorka studenata ne zna nijedan drugi strani jezik osim engleskog, što je slučaj sa 58\% ispitanika, dok samo $24 \%$ ispitanika zna i neki drugi strani jezik.

\section{Rezultati istraživanja}

Segment E (E39-E44) Inventara strategija za učenje jezika Rebeke Oksford obuhvata afektivne strategije koje su indirektne strategije i odnose se na osećanja učenika prilikom učenja engleskog jezika. 
Studenti poslovnog engleskog jezika (druga godina studija) na Visokoj poslovnoj školi u najmanjoj meri koriste afektivne strategije.

\begin{tabular}{|l|c|c|c|c|}
\hline & Minimum & Maximum & Aritmetička sredina & $\begin{array}{c}\text { Standardna } \\
\text { devijacija }\end{array}$ \\
\hline $\begin{array}{l}\text { E-AFEKTIVNE } \\
\text { STRATEGIJE }\end{array}$ & 6.00 & 25.00 & 13.3200 & 4.55551 \\
\hline
\end{tabular}

Tabela 2. Minimalni i maksimalni rezultati, aritmetičke sredine i standardne devijacije odgovora ispitanika na pitanja iz upitnika (Segment E: afektivne strategije)

$\mathrm{Na}$ osnovu dobijenih vrednosti aritmetičkih sredina sumacionih skorova za svaki segment možemo videti da u delu upitnika koji proverava afektivne strategije od mogućih 30 bodova ispitanici imaju oko 13 bodova.

U okviru ovog tipa strategija, postoje tvrdnje sa kojima se ispitanici slažu u većoj meri, pa se rezultati istraživanja mogu primeniti na uspešno učenje poslovnog engleskog jezika.

\begin{tabular}{|l|c|c|c|c|}
\hline & Minimum & Maximum & Aritmetička sredina & $\begin{array}{c}\text { Standardna } \\
\text { devijacija }\end{array}$ \\
\hline $\begin{array}{l}\text { E39. Pokušavam da se } \\
\text { opustim kad god osetim } \\
\text { strah od } \\
\text { upotrebe engleskog } \\
\text { jezika. }\end{array}$ & 1.00 & 5.00 & 2.5800 & 1.29505 \\
\hline $\begin{array}{l}\text { E40. Ohrabrujem sebe } \\
\text { da govorim na } \\
\text { engleskom jeziku } \\
\text { čak i kada me je strah } \\
\text { da ću pogrešiti. }\end{array}$ & $\mathbf{1 . 0 0}$ & $\mathbf{5 . 0 0}$ & $\mathbf{2 . 8 4 0 0}$ & $\mathbf{1 . 4 1 9 4 0}$ \\
\hline $\begin{array}{l}\text { E41. Nagrađujem sebe } \\
\text { kada nešto uspešno } \\
\text { odradim iz } \\
\text { oblasti engleskog jezika. }\end{array}$ & 1.00 & 5.00 & 2.2200 & 1.21706 \\
\hline $\begin{array}{l}\text { E42. Primećujem da sam } \\
\text { napet/a ili nervozan/a } \\
\text { kada } \\
\text { učim ili koristim engleski } \\
\text { jezik. }\end{array}$ & 1.00 & 5.00 & 2.4200 & 1.37158 \\
\hline $\begin{array}{l}\text { E43. Zapisujem svoja } \\
\text { osećanja u vezi sa } \\
\text { engleskim jezikom u } \\
\text { Dnevniku učenja. }\end{array}$ & 1.00 & 3.00 & & \\
\hline $\begin{array}{l}\text { E44. Razgovaram sa } \\
\text { drugima o tome kako se } \\
\text { osećam u procesu učenja } \\
\text { engleskog jezika. }\end{array}$ & 1.00 & 4.00 & 2.0200 & 1.05926 \\
\hline
\end{tabular}

Tabela 3. Minimalni i maksimalni rezultati, aritmetičke sredine i standardne devijacije odgovora ispitanika na pitanja iz upitnika (Segment E: afektivne strategije) 
Segment E pokazuje korišćenje afektivnih tehnika za učenje stranog jezika i na osnovu dobijenih rezultata možemo videti da ispitanici pokazuju najveću saglasnost sa tvrdnjom Ohrabrujem sebe da govorim na engleskom jeziku čak i kada me je strah da ću pogrešiti $(\mathrm{AS}=2,84)$. Rezultati pokazuju da je jezička anksioznost studenata na nižem nivou, što je dobar osnov za učenje engleskog jezika i uspeh u govornim vežbama.

Najmanju saglasnost ispitanici u istraživanju pokazali su sa sledećim tvrdnjama: Zapisujem svoja osećanja u vezi sa engleskim jezikom u Dnevniku učenja $(A S=1,24)$, Razgovaram sa drugima o tome kako se osećam u procesu učenja engleskog jezika $(\mathrm{AS}=2,02)$, Nagrađujem sebe kada nešto uspešno odradim iz oblasti engleskog jezika $(\mathrm{AS}=2,22)$, Primećujem da sam napet/a ili nervozan/a kada učim ili koristim engleski jezik $(\mathrm{AS}=2,42)$. Ono što nije u skladu sa prethodnim rezultatima jeste da ispitanici oklevaju da zapisuju svoja osećanja u vezi sa engleskim jezikom u Dnevniku učenja, a s druge strane imaju mehanizme ohrabrivanja da govore na engleskom jeziku čak i kada ih je strah da će pogrešiti. Komuniciranje sa drugima u grupi o tome kako se studenti osećaju u procesu učenja engleskog jezika izostaje, jer se studenti osećaju inhibirano da bi govorili o svojim strahovima i anksioznosti. Anksioznost pri učenju engleskog jezika je prisutna (Primećujem da sam napet/a ili nervozan/a kada učim ili koristim engleski jezik, $A S=2,42$ ), ipak postoje mehanizimi ohrabrivanja kod studenata. Studenti bi ipak trebali da u većoj meri nagrađuju sebe pri postignuću Nagrađujem sebe kada nešto uspešno odradim iz oblasti engleskog jezika $(\mathrm{AS}=2,22)$.

Potrebno je da nastavnici ohrabruju studente da zapisuju svoja osećanja u vezi sa engleskim jezikom u Dnevniku učenja, ali i da studenti razgovaraju sa drugima o tome kako se osećaju u procesu učenja engleskog jezika - motivacija od strane nastavnika i razmena osećanja i mišljenja ovde su bitni faktori. U zaključku, studentima je potrebno da koriste i poznaju afektivne strategije učenja budući da se smanjuje nivo anksioznosti, a povećava se nivo komuniciranja na engleskom jeziku. Bolja komunikacija na engleskom jeziku pomoći će studentima da budu u prilici da se permanentno usavršavaju u daljoj karijeri, budući da je engleski jezik lingua franca - jezik koji služi za međunarodnu komunikaciju i poslovno komuniciranje.

\section{Zaključak}

$\mathrm{Na}$ osnovu rezultata istraživanja, afektivne strategije su u manjoj upotrebi od strane studenata. Učenici se na početku učenja osećaju inhibirano da bi govorili o svojim strahovima i anksioznosti. Nastavnici treba da ohrabruju studente da iskažu svoja osećanja u vezi sa 
učenjem engleskog jezika. Studenti treba da, kroz komuniciranje sa nastavnikom i sa drugima u grupi, razviju komunikativne sposobnosti kako bi uspešno usmeno izlagali na engleskom jeziku.

\author{
Nina Kisin, \\ Novi Sad School of Business, Serbia
}

\title{
THE USAGE OF AFFECTIVE STRATEGIES FOR LEARNING IN BUSINESS ENGLISH LANGUAGE TEACHING
}

Abstract: This paper deals with the frequency of using affective strategies in English language teaching. Affective strategies are used to a lesser degree, as students at the beginning of learning feel inhibited to talk about their fears and anxiety. The research was conducted at the beginning of summer semester 2014/2015 with the students of Novi Sad School of Business. The aim of the research is to demonstrate whether and to what extent students use affective strategies for learning Business English. A quantitative method will be used for processing data derived from the results of Strategy Inventory for Language Learning (SILL) by Rebecca Oxford (Oxford, 1990). The results of the study show that affective strategies are used to a minimum. This paper aims to promote the use of affective strategies in English language teaching by students, since affective strategies are used to a lesser extent.

Key words: affective strategies, Business English.

1. Chamot, A.U. \& Kupper, L. (1989). Learning Strategies in Foreign Language

2. Instruction. Foreign Language Annals 22 (1); 13-22.

3. Ćirković-Miladinović, I. (2014). Zastupljenost afektivnih strategija učenja engleskog

4. jezika kod studenata na nematičnim fakultetima. Doktorska disertacija. Filozofski Fakultet, Univerzitet u Novom Sadu.

5. Karlak, M. (2014). Odnos strategija učenja, motivacije i komunikacijske jezične

6. kompetencije u stranom jeziku. Doktorska disertacija. Sveucilište Josipa Jurja Strossmayera, Filozofski Fakultet, Osijek. 
7. Kostić-Bobanović, M., i Ambrosi-Randić, N. (2006). Language Learning Strategies

8. in Different English as a Foreign Language Education Levels. Juraj Dobrila University of Pula, Pula.

9. Oxford, R. (1990). Strategy Inventory for Language Learning (SILL) in: Language

10. Learning Strategies: What Every Teacher Should Know. New York, NY: Newbury House Publisher.

11. Oxford R. (2003) Language learning styles and strategies: an overview, Learning Styles \& Strategies/Oxford, GALA. Retrieved July 22, 2014, from http://web.ntpu.edu.tw/ language/workshop/read2.pdf

12. White, J.C. (1993). Metacognitive, cognitive, social and affective strategy use in foreign language learning: a comparative study. A thesis presented in fulfilment of the requirements for the degree of $\mathrm{PhD}$ in Applied Linguistics. Massey University. 